\title{
Pendidikan Kesehatan Gizi pada Ibu Hamil di Desa Banjarsari Kecamatan Nglames Kabupaten Madiun
}

\author{
*Asasih Villasari \\ Prodi D3 Kebidanan Stikes Bhakti husada Mulia Madiun, Indonesia
}

\begin{abstract}
ABSTRAK
Status gizi masyarakat yang baik merupakan salah satu faktor penentu keberhasilan pembangunan kesehatan dan tidak terpisahkan dari pembangunan nasional secara keseluruhan. Gizi seimbang ibu hamil adalah keadaan keseimbangan antara gizi yang diperlukan oleh ibu hamil untuk kesehatan ibu dan pertumbuhan dan perkembangan janinnya yang dapat dipenuhi oleh asupan gizi dari aneka ragam makanan. Apabila Ibu hamil diberikan pendidikan mengenai gizi yang baik untuk meningkatkan asupan makanannya serta memperbaiki pola makannya, tidak hanya masalah anemia defisiensi besi saja yang teratasi namun resiko Kurang Energi Kronis juga akan menurun dan nantinya prevalensi kematian ibu dan lahirnya BBLR akan menurun, dengan demikian, kualitas sumber daya manusia akan meningkat. Dengan adanya antusiasme warga yang sangat bersemangat saat pelaksanaan penyuluhan pendidikan kesehatan diharapkan bisa meningkatkan wawasan dan pemahamannya tentang pentingnya gizi yang baik bagi ibu hamil di Banjarsari Kecamatan Nglames Kabupaten Madiun.
\end{abstract}

Kata kunci : Pola Hidup Bersih dan Sehat, Pengetahuan, Tindakan

\section{PENDAHULUAN}

Gizi seimbang ibu hamil adalah keadaan keseimbangan antara gizi yang diperlukan oleh ibu hamil untuk kesehatan ibu dan pertumbuhan dan perkembangan janinnya yang dapat dipenuhi oleh asupan gizi dari aneka ragam makanan.

Selama hamil, calon ibu memerlukan lebih banyak zat-zat gizi daripada wanita yang tidak hamil, karena makanan ibu hamil dibutuhkan untuk dirinya dan janin yang dikandungnya, bila makanan ibu terbatas janin akan tetap menyerap persediaan makanan ibu sehingga ibu menjadi kurus, lemah, pucat, gigi rusak, rambut rontok, dan lain-lain. Demikian pula, bila makanan ibu kurang tumbuh kembang janin akan terganggu, terlebih bila keadaan ibu pada masa sebelum hamil telah buruk pula. Keadaan ini dapat mengakibatkan abortus, BBLR, bayi lahir prematur atau bahkan bayi lahir mati. Pada saat bersalin dapat mengakibatkan persalinan lama,perdarahan, infeksi, dan kesulitan lain yang mungkin memerlukan pembedahan. Sebaliknya, makanan yang berlebih dapat mengakibatkan kenaikan berat badan yang berlebihan, bayi besar, dan dapat pula terjadi pre-eklamsi (keracunan kehamilan). Bila makanan ibu kurang kemudian di perbaiki setelah bayi lahir, kekurangan yang dialami sewaktu dalam kandungan tidak dapat sepenuhnya diperbaiki. 
Status gizi masyarakat yang baik merupakan salah satu faktor penentu keberhasilan pembangunan kesehatan dan tidak terpisahkan dari pembangunan nasional secara keseluruhan. Hal ini tercemin pada Indeks Pembangunan Manusia (IPM) yang terdiri dari umur harapan hidup, tingkat melek huruf dan pendapatan per kapita. IPM yang rendah antara lain dipengaruhi oleh status gizi dan kesehatan yang berdampak pada tingginya angka kematian bayi, balita dan ibu.

Ibu hamil yang menderita gizi kurang, baik gizi makro (Kurang Energi Kronis) maupun kurang gizi mikro seperti anemia dan GAKY berisiko melahirkan bayi dengan berat badan rendah dan berdampak pada pertumbuhan dan perkembangan anak,perkembangan intelektual serta produktivitas dikemudian hari. Oleh karena itu kurang gizi pada ibu hamil harus dihindari sehingga ibu hamil dapat melahirkan generasi yang berkualitas dan produktif Pada masa kehamilan, ibu membutuhkan tambahan zat gizi yang harus terpenuhi untuk pertumbuhan dan perkembangan janin. Kekurangan zat gizi makro mengakibatkan resiko ibu melahirkan bayi berat lahir rendah (BBLR) sedangkan kekurangan zat gizi mikro seperti mineral yaitu zat besi, Yodium, dan asam folat mengakibatkan anemia defisiensi besi, gangguan pertumbuhan pada anak, termasuk dengan berkurangnya kecerdasan (Intelligence Quotient/IQ), dan spina bifida pada bayi (Brown, 2012).

Anemia pada ibu hamil memberikan resiko yang berbahaya pada sang ibu yaitu pendarahan yang mengakibatkan kematian, baik pendarahan karena keguguran maupun saat persalinan. Anemia dapat meningkatkan resiko terjadinya pendarahan, sepsis, kematian ibu, kematian perinatal dan BBLR. Diperkirakan hampir semua wanita di dunia mengalami defisiensi besi, dan lebih dari 50\% ibu hamil di negara berkembang mengalami anemia. Dari seluruh kematian ibu, 40\% berhubungan dengan anemia (WHO, 2016).

Berdasarkan survey mengenai konsumsi ibu hamil yang Anemia Defisensi Besi di Posyandu Desa Banjarsari Kec.Nglames, prevalensi anemia defisiensi besi pada ibu hamil di desa banjarsari cukup tinggi, disebabkan oleh faktor konsumsi yang kurang dari Angka Kecukupan Gizi, dan adanya pola makan atau pola konsumsi yang kurang baik sehingga menurunkan kemampuan tubuh untuk menyerap zat besi. Zat besi banyak terdapat pada makanan yang tinggi protein. Asupan gizi makro terutama protein yang kurang secara otomatis meningkatkan resiko terjadinya anemia pada ibu hamil.

Apabila Ibu hamil diberikan pendidikan mengenai gizi yang baik untuk meningkatkan asupan makanannya serta memperbaiki pola makannya, tidak hanya masalah anemia defisiensi besi saja yang teratasi namun resiko Kurang Energi Kronis juga akan menurun dan nantinya prevalensi kematian ibu dan lahirnya BBLR akan menurun, dengan demikian, kualitas sumber daya manusia akan meningkat.

Oleh karena itu diperlukan upaya untuk memperbaiki status kesehatan terutama gizi ibu hamil supaya dapat mengurangi kematian ibu, meningkatkan kualitas hidup generasi penerus bangsa Indonesia dengan memberikan pendidikan gizi serta sosialisasi Pemberian Makanan Tambahan untuk Ibu Hamil di posyandu desa Banjarsari Kec. Nglames 


\section{METODE}

Metode yang digunakan selama penyuluhan yaitu metode ceramah. Dan pada akhir ceramah di adakan tanya jawab bila selama diadakannya ceramah ibu ada yang tidak mengerti, atau masih ada yang belum dipahami.

\section{Media}

LCD, Laptop, leaflet Gizi pada ibu hamil

\section{HASIL DAN PEMBAHASAN}

\begin{tabular}{|c|c|c|}
\hline $\begin{array}{c}\text { Tahap } \\
\text { Kegiatan } \\
\text { Penyuluhan } \\
\text { Kesehatan }\end{array}$ & $\begin{array}{l}\text { Kegiatan Penyuluhan } \\
\text { Kesehatan }\end{array}$ & Kegiatan Pasien dan Keluarga \\
\hline & $\begin{array}{l}\text { - Mengkaji tingkat pe- } \\
\text { ngetahuan ibu tentang } \\
\text { pemenuhan gizi pada ibu } \\
\text { hamil } \\
\text { - Memberika kesempatan } \\
\text { untuk bertanya } \\
\end{array}$ & $\begin{array}{l}\text { - Peserta penyuluhan me- } \\
\text { mahami tujuan dengan } \\
\text { baik } \\
\text { - Peserta penyuluhan mem- } \\
\text { perhatikan } \\
\text { - Mengajukan pertanyaan }\end{array}$ \\
\hline & $\begin{array}{l}\text { Memperhatikan reaksi ibu } \\
\text { hamil atau peserta } \\
\text { penyuluhan }\end{array}$ & $\begin{array}{l}\text { Peserta penyuluhan mem- } \\
\text { perhatikan, menunjukkan } \\
\text { reaksi antusias }\end{array}$ \\
\hline & $\begin{array}{ll}\text { - } & \text { Mengevaluasi tujuan } \\
\text { penyuluhan kesehatan }\end{array}$ & $\begin{array}{l}\text { Mampu } \\
\text { kembali }\end{array}$ \\
\hline
\end{tabular}

\section{SIMPULAN}

Hasil kegiatan Pengabdian Pendidikan Kesehatan ini dapat di aplikasikan untuk perubahan status gizi ibu hamil dalam kehidupan sehari-hari.

\section{DAFTAR PUSTAKA}

Depkes RI. Direktorat Pembinaan Kesehatan Masyarakat. 2017. Pedoman Penanggulangan Ibu Hamil Kekurangan Enargi Kronis. Jakarta.

Ummu Jabie. 2017. Gizi Tepat saat hamil.

Zulhaida, Lubis. 2013. Status Gizi Ibu Hamil Serta Pengaruhnya Terhadap Bayi Yang Dilahirkan.

http:// bidanku.com/index.php?/gizi-dan-nutrisi-ibu-hamil. 